\title{
ОСОБЕННОСТИ РЕАЛИЗАЦИИ ГОСУДАРСТВЕННЫХ ПРОГРАММ В СОЦИАЛЬНО-КУЛЬТУРНОЙ СФЕРЕ В РОССИЙСКОЙ ФЕДЕРАЦИИ
}

\author{
(C) 2019 Меликсетян Светлана Николаевна \\ кандидат экономических наук, доцент \\ Ростовский государственный экономический университет (РИНХ), Россия, Ростов-на-Дону \\ E-mail:m.s88@bk.ru \\ (c) 2019 Отришко Марина Олеговна \\ кандидат экономических наук, доцент кафедры «Финансы» \\ Ростовский государственный экономический университет (РИНХ), Россия, Ростов-на-Дону \\ E-mail:starka13@mal.ru
}

Одной из ключевых целей государственной финансовой политики Российской Федерации является обеспечение повышения благосостояния и улучшение качества жизни граждан. Особое внимание в данном процессе отводится формированию и реализации государственных программ социальной направленности. В статье представлены особенности реализации бюджетных государственных социальных программ, предложен алгоритм эффективного проведения бюджетного мониторинга и алгоритм организации деятельности учреждения социально-культурной сферы по достижению целевых показателей государственных программ.

Ключевые слова: социально-культурная сфера, расходы бюджета, программно-целевой метод, государственные программы, национальные проектыю.

В настоящее время в числе приоритетов государственной финансовой политики Российской Федерации находятся вопросы всестороннего гармоничного развития личности индивида в динамично меняющихся условиях цифровой экономики. В тоже время, формирование гармонично развитой личности и общества детерминирует обеспечение благоприятных условий для достойной жизни граждан и раскрытия способностей каждого индивида. Указанные задачи решаются в рамках функционирования социально-культурной сферы государства, именно через нее происходит реализация социальных функций государства посредством проведения социальной и культурной политики [1]. Таким образом, финансовое обеспечение социально-культурной сферы должно соответствовать ключевым направлениям государственной финансовой политики, реализуемой правительством страны и направленной на формирование социального государства.

Поскольку основным источником финансирования социально-культурной сферы выступают средства бюджетов бюджетной системы Российской Федерации, рассмотрим основные показатели расходов федерального бюджета в 2017-2021 гг. на социально-культурную сферу (таблица 1, [6]).
На основании данных, представленных в таблице 1 можно заключить:

- наибольший удельный вес в общей величине расходов федерального бюджета на социально-культурную сферу занимает социальная политика (около 70\% от всей суммы расходов на социально-культурную сферу); от 11\% до 13\% от объема расходов федерального бюджета на социально-культурную сферу планируются на образование и здравоохранение; на отрасль ЖКХ около 3\%;

- планируется увеличение расходов на образование (43,3\% или на 266 млрд. руб.), культуру и кинематографию (35,7\% или на 416 млрд. руб.) и ЖКХ (57,6\% или на 69 млрд. руб.);

- расходы на социальную политику снизятся примерно на 5\% или на 234 млрд. руб. в абсолютном выражении;

- наблюдается снижение расходов на физическую культуру и спорт (49\% или на 47 млрд. руб.) и средства массовой информации (27\% или на 14 млрд. руб.).

Ранее в научных исследованиях [1] мы отмечали, что, несмотря на государственное участие в развитии социально-культурной сферы, объемы ее финансового обеспечения представляются недостаточными для реализации всех целей государственной политики. В условиях 
Рисунок 1. Классификация расходов бюджетов на социально-культурную сферу

\begin{tabular}{|c|c|}
\hline Раздел расходов бюджета & Подразделы \\
\hline $\begin{array}{c}05 \text { Жилищно- } \\
\text { коммунальное хозяйство }\end{array}$ & $\begin{array}{c}\text { Жилищное хозяйство, коммунальное хозяйство, научные } \\
\text { исследования в области ЖКХ и др. }\end{array}$ \\
\hline 07 Образование & $\begin{array}{c}\text { Дошкольное образование, общее образование, } \\
\text { профессиональное образование, высшее образование; } \\
\text { молодежная политика, прикладные научные исследования в } \\
\text { области образования и др. }\end{array}$ \\
\hline $\begin{array}{c}08 \text { Культура и } \\
\text { кинематография }\end{array}$ & $\begin{array}{c}\text { Культура, кинематография, прикладные научные } \\
\text { исследования в области культуры и кинематографии и др. }\end{array}$ \\
\hline 09 Здравоохранение & $\begin{array}{c}\text { Медицинская амбулаторная и стационарная помощь, скорая } \\
\text { медицинская помощь, санитарно-эпидемиологическое } \\
\text { благополучие и др. }\end{array}$ \\
\hline 10 Социальная политика & $\begin{array}{c}\text { Пенсионное обеспечение, социальное обеспечение, охрана } \\
\text { семьи и детства и др. }\end{array}$ \\
\hline $\begin{array}{c}11 \text { Физическая культура и } \\
\text { спорт }\end{array}$ & Массовый спорт, спорт высших достижений и др. \\
\hline $\begin{array}{l}12 \text { Средства массовой } \\
\text { информации }\end{array}$ & $\begin{array}{c}\text { Телевидение и радиовещание, периодическая печать и } \\
\text { издательства и др. }\end{array}$ \\
\hline
\end{tabular}

Таблица 1. Расходы федерального бюджета на социально-культурную сферу в 2017-2021 гг., \%

\begin{tabular}{|l|c|c|c|c|c|c|}
\hline \multicolumn{1}{|c|}{ Показатель } & $\begin{array}{c}2017 \\
\text { (исполнено) }\end{array}$ & $\begin{array}{c}2018 \\
\text { (план) }\end{array}$ & $\begin{array}{c}2019 \\
(\text { план) }\end{array}$ & $\begin{array}{c}2020 \\
\text { (план) }\end{array}$ & $\begin{array}{c}2021 \\
\text { (план) }\end{array}$ & $\begin{array}{c}\text { Темп роста } \\
2021 \text { г. к 2017 г. }\end{array}$ \\
\hline Всего & 100 & 100 & 100 & 100 & 100 & 107,6 \\
\hline ЖКХ & 1,8 & 2,4 & 2,8 & 2,8 & 2,7 & 157,6 \\
\hline Образование & 9,6 & 11,1 & 12,2 & 11,9 & 12,7 & 143,3 \\
\hline Культура, кинематография & 1,4 & 1,7 & 1,8 & 1,6 & 1,8 & 135,7 \\
\hline Здравоохранение & 6,8 & 7,7 & 9,6 & 12,9 & 12,4 & 194,5 \\
\hline Социальная политика & 77,6 & 74,8 & 71,7 & 69,1 & 68,7 & 95,3 \\
\hline Физическая культура и спорт & 1,5 & 1,0 & 0,8 & 0,8 & 0,7 & 51,6 \\
\hline СМИ & 1,3 & 1,4 & 1,1 & 1,0 & 1,0 & 82,8 \\
\hline
\end{tabular}


нестабильной экономической ситуации на мировых рынках энергоносителей, экономических санкций и незначительных темпов роста ВВП в последние годы для России в среднесрочной перспективе не представляется возможным существенно увеличить бюджетные расходы на отрасли социально-культурной сферы. В этой связи актуализируется необходимость проведения ряда мероприятий, которые позволят выявить резервы роста финансовых ресурсов организаций социально-культурной сферы посредством повышения эффективности и результативности использования предоставляемых бюджетных средств [2; 3].

В мировой практике бюджетного планирования общепризнанным и наиболее действенным способом повышения эффективности и результативности государственных расходов является программно-целевой метод бюджетного планирования. Важным инструментом программно-целевого метода планирования выступают государственные программы, позволяющие комплексно и системно достигать среднесрочные и долгосрочные цели экономической политики страны, обеспечивать прозрачность и обоснованность выбора целей, которые необходимо реализовать в различные временные периоды, а также способы достижения заданных результатов.

Следует отметить, что с 2006 года существовали отдельные попытки применения и апробации в российских условиях программно-целевого метода бюджетного планирования: так, был разработан и реализован ряд ведомственных и федеральных целевых программ на федеральном и региональном уровнях. Однако завершающим этапом внедрения программно-целевого метода планирования бюджетных расходов следует считать 2014-2016 гг., когда были сформировано 39 государственных программ (включали в себя реализуемые на тот период федеральные целевые программы), сгруппированных по пяти основным направлениям. В настоящее время в Российской Федерации реализуются 43 государственные программы [4].

В Российской Федерации в рамках реализации целей бюджетной, налоговой и таможенно-тарифной политики на 2019-2021 по направлению стратегической приоритизации расходов бюджета разработан ряд национальных проектов, особенно в социально-культурной сфере (таблица 2) [5; 6].

По данным таблицы 2 можно заключить, что наибольшую долю в расходах на социально-культурную сферу занимает национальный проект «Демография» - около 30\% от общей суммы расходов в 2019 году; расходы бюджета на реализацию нацпроекта «Здравоохранение» составляют в среднем $12 \%$ от общей суммы расходов; около 6\% расходов - на нацпроекты «Образование» и «Жилье и городская среда». Нацпроекты «Наука» и «Культура» в совокупности составляют 3\% от общей суммы расходов, что свидетельствует о проблеме остаточного финансирования данных отраслей.

Отметим, что существующие параллельно государственные программы, национальные проекты, федеральные проекты не противоречат

Таблица 2. Параметры финансового обеспечения национальных проектов социально-культурной сферы в 2019-2022 гг.

\begin{tabular}{|c|c|c|c|c|c|c|c|c|c|c|}
\hline \multirow[b]{2}{*}{ Наименование } & \multicolumn{2}{|c|}{2019} & \multicolumn{2}{|c|}{2020} & \multicolumn{2}{|c|}{2021} & \multicolumn{2}{|c|}{2022} & \multicolumn{2}{|c|}{ Всего } \\
\hline & $\begin{array}{l}\text { млрд. } \\
\text { руб. }\end{array}$ & $\%$ & $\begin{array}{l}\text { млрд. } \\
\text { руб. }\end{array}$ & $\%$ & $\begin{array}{l}\text { млрд. } \\
\text { руб. }\end{array}$ & $\%$ & $\begin{array}{l}\text { млрд. } \\
\text { руб. }\end{array}$ & $\%$ & $\begin{array}{l}\text { млрд. } \\
\text { руб. }\end{array}$ & $\%$ \\
\hline $\begin{array}{l}\text { Всего по всем нацио- } \\
\text { нальным проектам }\end{array}$ & 1685,5 & 100 & 1862,7 & 100 & 2084,8 & 100 & 2512,5 & 100 & 8145,5 & 100 \\
\hline $\begin{array}{l}\text { Всего по проектам } \\
\text { социально-культурной } \\
\text { сферы }\end{array}$ & 928,2 & 55,1 & 1099,2 & 59 & 1073,9 & 51,5 & 1120,3 & 44,6 & 4221,6 & 51,8 \\
\hline \multicolumn{11}{|c|}{ В том числе национальные проекты: } \\
\hline НП «Демография» & 512 & 30,4 & 522,2 & 28,0 & 528,8 & 25,4 & 474,5 & 18,9 & 2037,5 & 25 \\
\hline НП «Здравоохранение» & 159,8 & 9,5 & 299,1 & 16,1 & 238,8 & 11,5 & 256,1 & 10,2 & 953,8 & 11,7 \\
\hline НП «Образование» & 103,2 & 6,1 & 117,6 & 6,3 & 127,7 & 6,1 & 116,6 & 4,6 & 465,1 & 5,7 \\
\hline $\begin{array}{l}\text { НП «Жилье и город- } \\
\text { ская среда» }\end{array}$ & 105,3 & 6,2 & 105,3 & 5,7 & 108,4 & 5,2 & 172,8 & 6,9 & 491,8 & 6 \\
\hline НП «Наука» & 35,2 & 2,1 & 41,4 & 2,2 & 53,5 & 2,6 & 80,4 & 3,2 & 210,5 & 2,6 \\
\hline НП «Культура» & 12,7 & 0,8 & 13,6 & 0,7 & 16,7 & 0,8 & 19,9 & 0,8 & 62,9 & 0,8 \\
\hline
\end{tabular}


друг другу и не являются дублирующими. Наоборот, данные программные документы конкретизируют отдельные направления деятельности. Национальный проект включает совокупность федеральных проектов, которые уже содержатся в подпрограммах государственных программ. Кроме того, в формате национальных проектов решена проблема параллельного существования и реализации двух инструментов программно-целевого планирования: государственных программ и федеральных целевых программ. С 1 января 2018 года по решению Правительства Российской Федерации прекращена реализация федеральных целевых программ, которые интегрированы в пилотные госпрограммы.

Таким образом, реализуемые национальные проекты и государственные программы ориентированы на достижение ключевых целей социальной и культурной политики государства, оптимального соотношения результатов и затрат, произведенных с целью сохранения и преумножения культурного наследия, обеспечения благосостояния граждан.

Следует отметить, что эффективность реализации государственных программ во многом зависит от деятельности государственных учреждений, непосредственно оказывающих социально-культурные услуги населению. В этой связи необходимо совершенствовать организацию как функциональной, так и финансово-хозяйственной деятельности каждого отдельного учреждения в контексте достижения целевых показателей, установленных государственными программами и национальными проектами.

С нашей точки зрения, функциональная и финансово-хозяйственная деятельность организаций социально-культурной сферы в настоящее время не ориентирована на достижение показателей эффективности и результативности в силу того, что в самих государственных программах существует немало методологических неточностей, многие показатели не конкретизированы и трудно измеримы. В этих условиях организациям социально-культурной сферы при планировании финансово-хозяйственной и функциональной деятельности на предстоящий период следует применять SWOT-анализ текущего состояния учреждения и соотносить возможности достижения обозначенных в госпрограммах показателей с тем потенциалом, который имеется на настоящий момент.

Отметим, что государственные программы, безусловно, являются эффективным инструментом реализации стратегических целей государственной финансовой политики в социокультурной сфере. Однако до настоящего времени их реализация не всегда проходит наилучшим образом, что детерминируется в основном отсутствием пока еще длительного опыта их реализации, а также дублированием мероприятий в рамках подпрограмм, несвоевременности и длительности исполнения отдельных мероприятий, методологически непроработанной системы оценки качества и результативности реализации госпрограмм. Особого внимания в данном контексте заслуживают вопросы теории и практики применения должных мер пресечения не только за нецелевое, но и за неэффективное использование бюджетных средств, что, по мнению авторов, еще более актуализирует проблемы обеспечения национальной безопасности страны. Все эти проблемы тормозят реализацию государственных программ в непростых кризисных условиях, и требуют незамедлительного решения на законодательном уровне.

Резюмируя выше изложенное, следует заключить, что процесс нивелирования всех выявленных недостатков программно-целевого планирования, в целом, и государственных программ, в частности, заключается в следующем:

- четкое разделение проблем, решаемых исключительно на федеральном уровне, и тех, которые можно решить на уровне субъектов федерации при планировании и утверждении государственных федеральных и государственных региональных программ, что позволит совершенствовать механизм их финансового обеспечения;

- уточнение отдельных процедур оценки результативности и эффективности реализации государственных программ. Представляется, что оценка качества и результативности мероприятий государственных программ должна стать отдельным разделом в документах стратегического планирования. Объективная оценка эффективности государственных программ Российской Федерации на основе методологии эффективности инвестиционных проектов, социальной эффективности, использование различных источников информации с целью объективной оценки полученных результатов повысит результативность использования бюджетных средств, снизит коррупционные риски в управлении общественными финансами; 
- разработка и конкретизация показателей эффективности и результативности при оценке реализации государственных программ. Как показывает анализ, в отдельных сегментах социально-культурной сферы, находящихся не под столь пристальным вниманием органов государственной власти и местного самоуправления (в частности, молодежная политика), несмотря на наличие такого стратегического документа как «Основы государственной молодежной политики Российской Федерации на период до 2025 года», до сих пор отсутствуют какие-либо критерии и измеримые показатели, позволяющие оценить эффективность производимых расходов в данном сегменте и конечный результат.

\section{Библиографический список}

1. Меликсетян С.Н. Финансовый аспект реализации концепции социального государства в России // Финансовая аналитика: проблемы и решения.2016.№ 20 (302).- С.46-60.

2. Глушакова О.В. Современные тренды и проблемы развития национальной системы публичного управления общественными финансами // Финансы и кредит. 2019. № 6.- С.1353-1372.

3. Романова Т.Ф., Максимов А.В., Андреева О.В., Отришко М.О. Современные вызовы финансовой политики государства в социальной сфере // European Research Studies Journal, Volume XXI, Special Issue 1, 387-396, 2018

4. Гайдаржи С.И., Сычева Н.А. Эволюция методологии и современные проблемы разработки инвестиционной составляющей социальных государственных программ //Бухгалтерский учет в бюджетных и некоммерческих организациях. 2018. № 5 (437).- С. 13-26.

5. Бозиева И.А. Финансирование инноваций: национальные проекты и необходимость новых инструментов // Финансы и кредит. 2019. № 5.- С. 1043-1060.

6. Официальный сайт Правительства Российской Федерации. URL: http://government.ru/ 